\title{
Use of Industrial Waste Slag in Alkali-Activated Slag Ceramsite Concrete Hollow Blocks
}

\author{
Zhenzhen Jiao ${ }^{1,2,3}$, Ying Wang ${ }^{1,2,3}$, Wenzhong Zheng $1,2,3, * \mathbb{D}$, Wenxuan Huang ${ }^{1,2,3}$ and \\ Xianyu Zhou 1,2,3 \\ 1 School of Civil Engineering, Harbin Institute of Technology, Harbin 150090, China; \\ jiaozhenzhen@hit.edu.cn (Z.J.); wangying888@hit.edu.cn (Y.W.); wenxuan911018@163.com (W.H.); \\ hitzxy@stu.hit.edu.cn (X.Z.) \\ 2 Key Lab of Structures Dynamic Behavior and Control of the Ministry of Education, Harbin Institute of \\ Technology, Harbin 150090, China \\ 3 Key Lab of Smart Prevention and Mitigation of Civil Engineering Disasters of the Ministry of Industry and \\ Information Technology, Harbin Institute of Technology, Harbin 150090, China \\ * Correspondence: zhengwenzhonghit@163.com; Tel.: +86-451-86282087
}

Received: 5 October 2018; Accepted: 20 November 2018; Published: 22 November 2018

\begin{abstract}
In this paper, a parametric experimental study developing the alkali-activated slag concrete hollow block (AASCHB) is discussed. Fourteen trial mixes of alkali-activated slag concrete containing pottery sand and ceramsite with different water-to-slag ratios, sand ratios, silicate moduli, and $\mathrm{Na}_{2} \mathrm{O}$ contents were evaluated to determine the optimal mix for high compressive strength and low drying shrinkage. All four factors evaluated were found to be significant for the desired properties. A series of $390 \times 190 \times 190 \mathrm{~mm}^{3}$ AASCHBs were prepared using the optimal mix with a water-to-slag ratio of 0.35 , sand ratio of 0.64 , silicate modulus of 1.2 , and $\mathrm{Na}_{2} \mathrm{O}$ content of $8 \%$. The compressive strength, flexural strength, water absorption, and moisture content tests of these blocks indicate that the resulting AASCHB can be classified under the strength grade of MU15 as a load-bearing hollow concrete block. The proposed AASCHBs appear to provide a viable solution to the environmental problems of industrial waste and cement production emissions, leading to more sustainable buildings without compromising structural performance.
\end{abstract}

Keywords: alkali-activated slag concrete; hollow concrete block; compressive strength; concrete mix ratios; drying shrinkage

\section{Introduction}

As the demand for steel has increased during the current era of rapid economic development, the production of industrial by-products, such as blast furnace slag, has also increased around the world. The accumulation of blast furnace slag is a form of pollution, which represents a significant environmental problem. About 2.4 million tons of slag is produced every year, and only a small amount of this is used efficiently, meaning most of the remainder is considered to be solid industrial waste [1,2]. The slag has been used in the past as a substitute for Portland cement in concrete production due to its latent hydraulicity [3]. The workability and mechanical performance of concrete with slag cement (with the content of slag used as $25 \%$ replacement of the weight of the cement) were investigated by Parron-Rubio et al. [4]. Berndt [5] studied the chloride diffusion, sulfate resistance, and permeability of the concrete mixed with slag as the replacement for cement. Furthermore, the production of conventional Portland cement is responsible for considerable atmospheric pollution, including carbon dioxide emissions. Blast furnace slag can be applied completely, using an alkali-activator, in place of Portland cement. As a result, there have been many investigations on the potential utilization of blast 
furnace slag in the production of building materials for the construction industry to help preserve natural resources, reduce pollution, and thus better maintain ecological balance.

Alkali-activated cementitious material is an inorganic binder consisting of a mixture of alkaline activator and silicate cementitious materials, such as fly ash, metakaolin, phosphorous slag, steel slag, or blast furnace slag [6]. Many researchers have indicated that alkali-activated slag concrete (AASC) provides excellent mechanical performance [7,8], good durability $[9,10]$, and fast setting times [11,12]. In general, the key parameters determining the properties of AASC are the composition of materials, type of alkaline activator, and the admixtures used $[11,13,14]$. The workability of alkali-activated slag (AAS) pastes has been found to be better and the slump higher as the liquid-to-solid ratios increase from 0.45 to 0.60 , but the compressive strength is typically lower [15]. It has also been reported that a higher content of alkali agent decreases the setting time and increases the compressive strength and ultrasonic pulse velocity in AAS pastes [16]. The compressive strength of AASC has been found to increase notably in the first three days to about 3.5-5 times the level of ordinary Portland cement [17]. The compressive strength of AASC activated by sodium silicate solution can reach $64.5 \mathrm{MPa}$, which is much larger than that by sodium hydroxide (15.6 MPa) after 28 days [7]. The main reason for this is that the slag activated by sodium hydroxide forms a denser C-S-H with less chemically bound water in the initial reaction, which results in an increase in coarse porosity at a later age and lower mechanical performance [18]. However, there is an opposite trend in terms of the drying shrinkage of AAS activated by the above two alkaline activators [19]. A direct relationship has been observed between drying shrinkage and pore structures [20], with finer pore size distribution resulting in increased drying shrinkage while improving the compressive strength $[21,22]$. The silicate modulus and alkali content have been found to be the main parameters for the properties of the slag activated by water glass [23-25]. The optimum silicate modulus and sodium concentration in terms of fresh and hardened properties of AAS are due to the excess alkali being unable to fully react with the slag [26]. A previous study determined that the compressive strength, permeability, water sorption, and carbonation resistance properties of AASC can be improved with higher binder contents [8], resulting in an AASC with a refined, complex, and closed porous structure [20]. Generally, the drying shrinkage of AAS pastes has been found to be much higher than that of AAS mortars due to the presence of fine aggregate, which inhibits shrinkage. Furthermore, AASC exhibits lower water absorption and higher flexural strength compared to ordinary Portland cement. Notably, the referenced studies all concentrated on investigating the properties of solid AASC cubes, not hollow blocks, which are the subject of the current study.

The conventional hollow concrete block is a large rectangular brick that is widely used in construction. Concrete blocks are typically made from cast concrete, i.e., Portland cement and aggregate (usually a type of small-sized gravel) with sufficient water content to produce the desirable mixture properties. In Chinese factories, these blocks are generally prepared by an auto-compaction machine under pressure and vibration, then placed in a steam curing room at a temperature of $60-80{ }^{\circ} \mathrm{C}$ for 1 day before being cured at room temperature for 28 days. The demand for hollow concrete blocks has increased and so has the total production of cement. Because the production of cement is responsible for a significant amount of pollution, the development of new materials for hollow concrete blocks is an essential subject of research. Alkali-activated slag concrete exhibit fast setting time and high early strength, and they can demould in short time, making them suitable for preparing AASCHB without high-temperature curing. Ceramsite and pottery sand, a kind of highly dimensionally stable aggregate, have been used as the aggregate for AASC, which can decrease the drying shrinkage due to the reduction of paste content $[27,28]$. A previous study [29] demonstrated that AASC has good potential for application in unitized masonry, an industry in which small sizes and a controlled setting offer an ideal environment for packing optimization by mechanical compaction, which has been demonstrated to increase the strength and durability of soil cement, alkali-activated clays, and other aggregate blends [30].

Though researchers have studied the basic mechanical properties of AASC, no study has described the use of AASC with pottery sand (as a fine aggregate) and ceramsite (as a coarse aggregate), both of 
which offer significant benefits for use in concrete blocks. Accordingly, the effects of the water-to-slag ratio, sand ratio, silicate modulus, and $\mathrm{Na}_{2} \mathrm{O}$ content on the compressive strength and drying shrinkage of AASC incorporating these materials were investigated in this paper to investigate the behavior of a new type of AASCHB. The outcome of this research is a new high-performance AASCHB that can be useful in practical construction while reducing the environmental impact of the construction industry. This study determined that the optimal AASC mix for hollow concrete blocks has a water-to-slag ratio of 0.35 , a sand ratio of 0.64 , a silicate modulus of 1.2 , and a $\mathrm{Na}_{2} \mathrm{O}$ content of $8 \%$ for optimal workability, high compressive strength, and low drying shrinkage. The resulting AASCHB can be classified under strength grade of MU15 and has been determined to be appropriate for use as a load-bearing hollow concrete block.

\section{Materials and Methods}

\subsection{Materials}

\subsubsection{Alkaline Activator}

The alkaline activator used for the AASC in this study was prepared using water glass and sodium hydroxide. The water glass was supplied by Julide Chemical Co., Langfang, China and contained $10.3 \%, 32.1 \%$, and $57.6 \%$ of $\mathrm{Na}_{2} \mathrm{O}, \mathrm{SiO}_{2}$, and $\mathrm{H}_{2} \mathrm{O}$, respectively. Sodium hydroxide pellets with a purity of $96 \%$ were supplied by Dalu Chemical Reagent Factory, Tianjin, China.

\subsubsection{Blast Furnace Slag}

Blast furnace slag, classified as S95 according to Chinese Standard GB/T 18046-2008 with a specific surface area of $349 \mathrm{~m}^{2} / \mathrm{kg}$, was procured from the Shandong steel plant, China. The chemical composition of the blast furnace slag as determined by $\mathrm{X}$-ray fluorescence (XRF) is provided in Table 1. A photograph and the X-ray diffraction (XRD) analysis of the slag are shown in Figure 1a,b, respectively. Notably, the XRD analysis of the slag exhibited an amorphous hump at about $30^{\circ}$, indicating a significant presence of glass.

Table 1. Chemical composition of blast furnace slag (\%).

\begin{tabular}{cccccccccc}
\hline Oxide & $\mathrm{SiO}_{2}$ & $\mathrm{Al}_{2} \mathbf{O}_{3}$ & $\mathrm{CaO}$ & $\mathrm{Fe}_{2} \mathbf{O}_{3}$ & $\mathbf{K}_{\mathbf{2}} \mathbf{O}$ & $\mathbf{M g O}$ & $\mathbf{N a}_{2} \mathbf{O}$ & $\mathrm{SO}_{3}$ & $\mathbf{P}_{\mathbf{2}} \mathrm{O}_{5}$ \\
\hline Slag & 36.08 & 10.22 & 42.01 & 0.33 & 0.71 & 8.27 & 0.41 & 1.95 & 0.02 \\
\hline
\end{tabular}

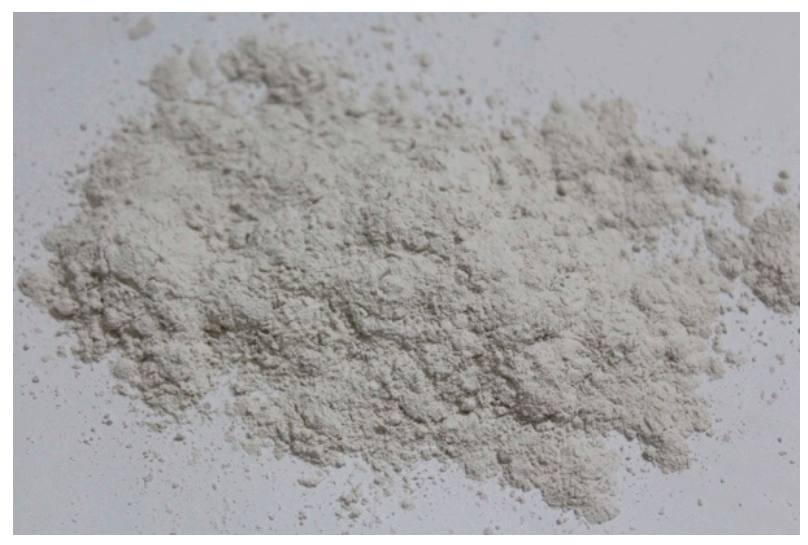

(a)

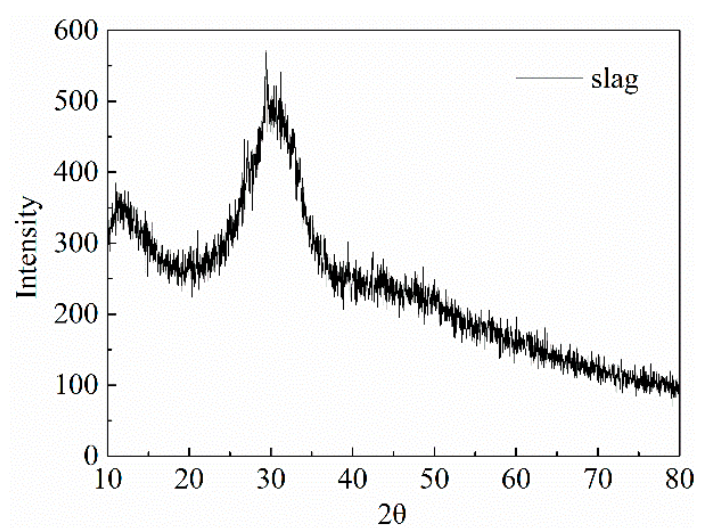

(b)

Figure 1. Blast furnace slag: (a) photograph; (b) XRD diffractogram. 


\subsubsection{Coarse Aggregate and Fine Aggregate}

Pottery sand was prepared from fly ash and bauxite calcining at a temperature of $1200-1600{ }^{\circ} \mathrm{C}$ and used as a fine aggregate in the subject AASC. The particle size of the pottery sand was $\leq 1 \mathrm{~mm}$, and the specific gravity and bulk density were 1.8 and $1.2 \mathrm{~g} / \mathrm{cm}^{3}$, respectively. The chemical composition of the pottery sand is provided in Table 2. Ceramsite, an artificial lightweight aggregate mainly produced from fly ash and moderate amounts of lime, gypsum, and admixtures at a temperature of $1000-1400{ }^{\circ} \mathrm{C}$, was used as the coarse aggregate in the subject AASC. The ceramsite particle sizes were classified into $5-10 \mathrm{~mm}$ and $10-16 \mathrm{~mm}$ groups, with a bulk density of $0.83 \mathrm{~g} / \mathrm{cm}^{3}$ and water absorption of $20 \%$. The compressive cylinder strength of the ceramsite was 4.2 MPa. Figure 2 shows images of the pottery sand (Figure 2a), 5-10 mm ceramsite (Figure $2 \mathrm{~b}$ ), and 10-16 $\mathrm{mm}$ ceramsite (Figure 2c).

Table 2. Chemical composition of pottery sand (\%).

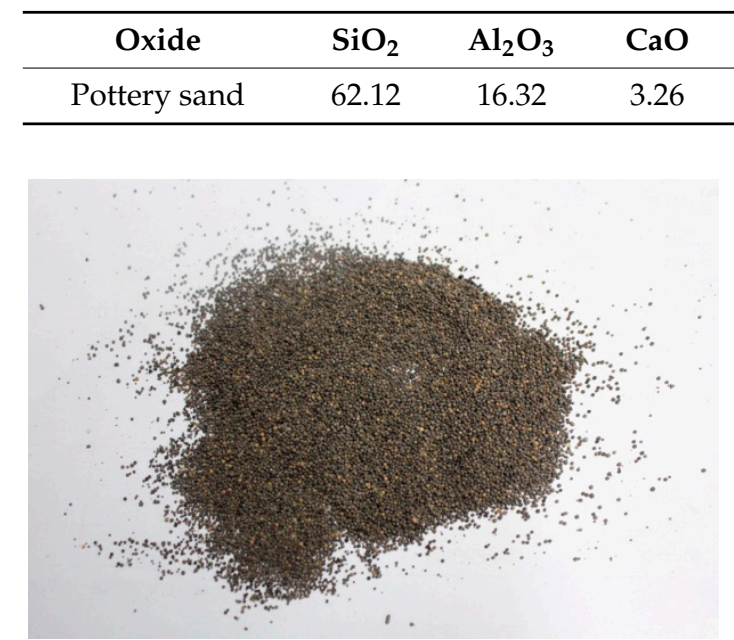

(a)

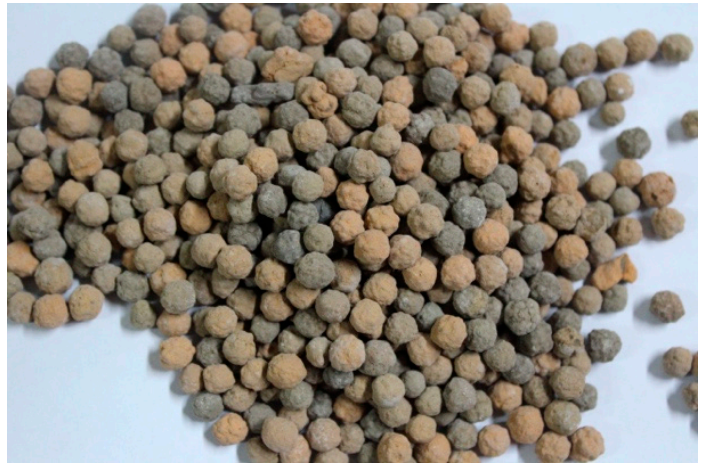

(b)

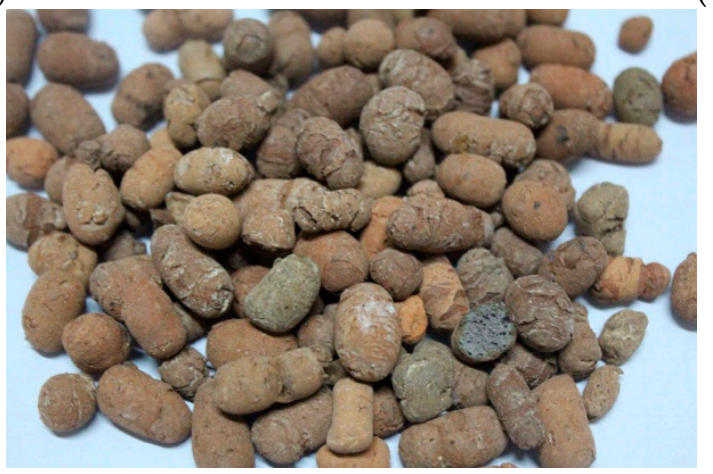

(c)

Figure 2. Images of (a) pottery sand; (b) 5-10 mm ceramsite; (c) 10-16 mm ceramsite.

\subsection{Evaluated Mixes}

\subsubsection{Mix Proportions}

During the first stage of the study, the optimum water-to-slag ratios $(0.35,0.38$, and 0.40$)$ and sand ratios (mass of fine aggregate to the total mass of fine and coarse aggregates of 0.54, 0.59, 0.64, and 0.68) were determined. Using the resulting optimum mix, the properties of AASC with different silicate moduli $\left(1.2,1.4\right.$, and 1.6) and $\mathrm{Na}_{2} \mathrm{O}$ contents $(6 \%, 8 \%$, and $10 \%)$ of the alkaline activator were investigated. In all, a total of 14 different mixtures were prepared, cast, and tested to determine their respective compressive strengths and drying shrinkages. Table 3 describes the mix proportions of the tested AASC specimens. 
Table 3. Mix proportions used in this study (g).

\begin{tabular}{|c|c|c|c|c|c|c|c|}
\hline $\operatorname{Mix}^{1}$ & Water Glass & $\mathrm{NaOH}$ & $\mathrm{H}_{2} \mathrm{O}$ & Slag & Pottery Sand & Ceramsite (10-16 mm) & Ceramsite $(5-10 \mathrm{~mm})$ \\
\hline W35P59 & 289.9 & 64.5 & 168.5 & 1000 & 1511.6 & 732.6 & 314.0 \\
\hline W38P59 & 289.9 & 64.5 & 198.5 & 1000 & 1511.6 & 732.6 & 314.0 \\
\hline W40P59 & 289.9 & 64.5 & 218.5 & 1000 & 1511.6 & 732.6 & 314.0 \\
\hline W35P54 & 289.9 & 64.5 & 168.5 & 1000 & 1322.7 & 793.6 & 340.1 \\
\hline $\begin{array}{c}\text { W35P64 } \\
\text { (M1.2N8) }\end{array}$ & 289.9 & 64.5 & 168.5 & 1000 & 1700.6 & 671.5 & 287.8 \\
\hline W35P68 & 289.9 & 64.5 & 168.5 & 1000 & 1889.5 & 610.5 & 261.6 \\
\hline M1.2N6 & 217.4 & 48.4 & 213.9 & 1000 & 1700.6 & 671.5 & 287.8 \\
\hline M1.2N10 & 362.3 & 80.6 & 123.2 & 1000 & 1700.6 & 671.5 & 287.8 \\
\hline M1.4N6 & 253.2 & 43.5 & 194.1 & 1000 & 1700.6 & 671.5 & 287.8 \\
\hline M1.4N8 & 338.2 & 58.1 & 142.1 & 1000 & 1700.6 & 671.5 & 287.8 \\
\hline M1.4N10 & 422.7 & 72.6 & 90.2 & 1000 & 1700.6 & 671.5 & 287.8 \\
\hline M1.6N6 & 289.9 & 38.7 & 174.3 & 1000 & 1700.6 & 671.5 & 287.8 \\
\hline M1.6N8 & 386.5 & 51.6 & 115.8 & 1000 & 1700.6 & 671.5 & 287.8 \\
\hline M1.6N10 & 483.1 & 64.5 & 57.2 & 1000 & 1700.6 & 671.5 & 287.8 \\
\hline
\end{tabular}

${ }^{1} \mathrm{~W}=$ water-to-slag ratio; $\mathrm{P}=$ mass ratio of pottery sand to the total of pottery sand and ceramsite; $\mathrm{M}=$ silicate modulus; $\mathrm{N}=\mathrm{Na}_{2} \mathrm{O}$ content.

In Table 3, mix W35P59, for example, indicates a water-to-slag ratio of 0.35 and sand ratio of 0.59 based on a silicate modulus of 1.2 and $\mathrm{Na}_{2} \mathrm{O}$ content of $8 \%$ for the alkaline activator, while mix M1.2N6 indicates a silicate modulus of 1.2 and $\mathrm{Na}_{2} \mathrm{O}$ content of $6 \%$ for the alkaline activator based on a water-to-slag ratio of 0.35 and sand ratio of 0.64 . Compressive strength and drying shrinkage tests were conducted on samples of all 14 mixtures, and the best-performing mix of all 14 (determined based on the compressive strength and drying shrinkage) was selected for further investigation of the properties of the proposed AASCHB.

\subsubsection{Mix Test Specimen Preparation}

To prepare the AASC specimens, the slag, pottery sand, and ceramsite were first premixed for $5 \mathrm{~min}$ in a concrete mixer to well homogenize them; then, the activator was added and all mixtures were stirred for an additional $1 \mathrm{~min}$.

The compressive strength test specimens were prepared in accordance with the requirements of Chinese Standard GB/T 50081-2002. The fresh concrete mixtures were poured into $100 \mathrm{~mm}$ cubic molds and then mechanically shaken. Next, plastic foil was used to seal the top surface of the samples to avoid any loss of moisture. After $24 \mathrm{~h}$, the samples were demolded (Figure 3) and placed in a standard curing room (relative humidity $>95 \%$, air temperature of $20 \pm 2{ }^{\circ} \mathrm{C}$ ) until the time of the test. Three cubes were cast of each mixture for each evaluated curing age.

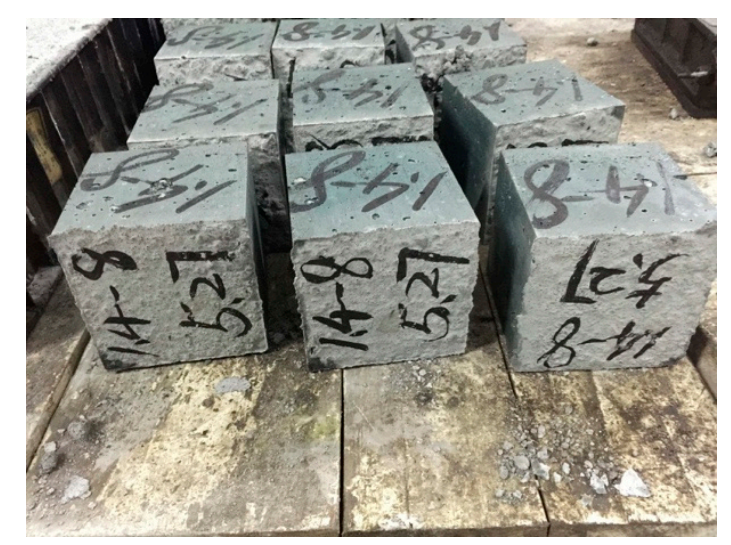

Figure 3. Compressive strength test specimens.

The drying shrinkage test specimens were prepared according to Chinese Standard GB/T 50082-2009. The fresh concrete was cast into $100 \times 100 \times 400 \mathrm{~mm}^{3}$ prismatic molds. The remaining procedure was the same as for the compressive strength specimens until demolding. The demolded 
samples were stored in isothermal chambers (relative humidity of $50 \pm 5 \%$, air temperature of $20 \pm 2{ }^{\circ} \mathrm{C}$ ), as shown in Figure 4. Two prisms were cast of each mixture.

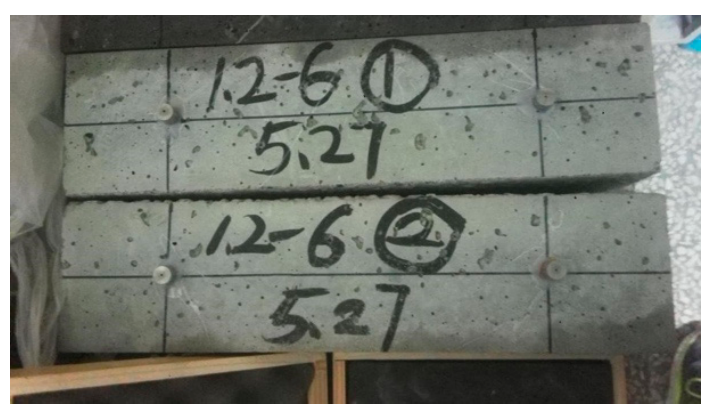

Figure 4. Drying shrinkage test specimens.

\subsection{Preparation of Concrete Block Specimens}

To the best of our knowledge, no studies describing the performance of alkali-activated slag concrete (using pottery sand and ceramsite as the fine and coarse aggregates, respectively) as a hollow concrete block material have been published. Therefore, an initial investigation of AASCHB performance was conducted as a part of this study. Homemade plexiglass concrete block molds were accordingly fabricated with internal length, width, and depth of 390, 190, and $190 \mathrm{~mm}$, respectively, and two hollow cavities for a total void content of $48.3 \%$, as shown in Figure 5a. The fresh concrete was prepared as described in Section 2.2.2 (Figure 5b), then poured into the concrete block mold (Figure 5c), followed immediately by mechanical vibration (Figure $5 \mathrm{~d}$ ). The partially cured AASCHBs were demolded after curing for 5-10 min (Figure $5 \mathrm{e}-\mathrm{g}$ ), then cured in a standard curing room for 28 days. A completed AASCHB is shown in Figure $5 \mathrm{~h}$.

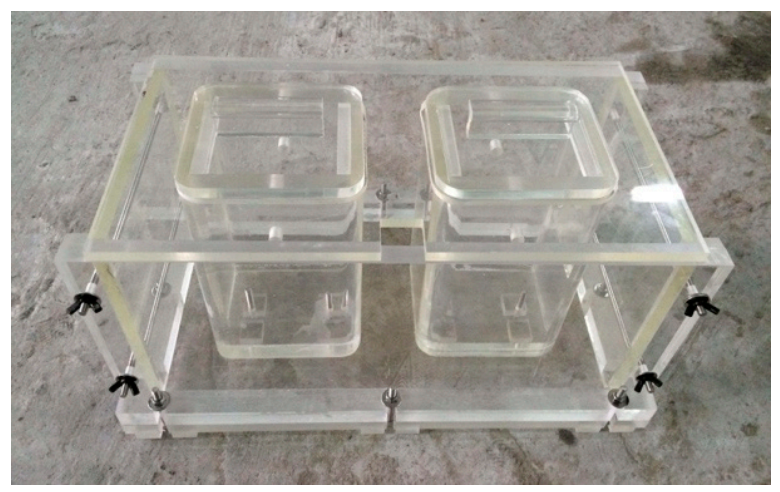

(a)

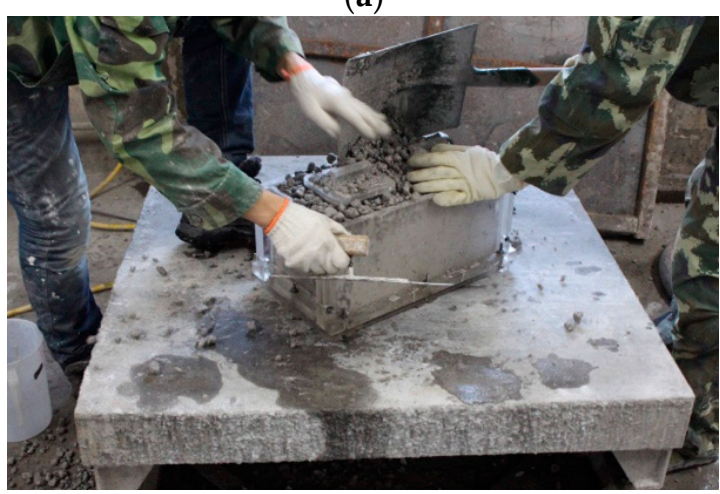

(c)

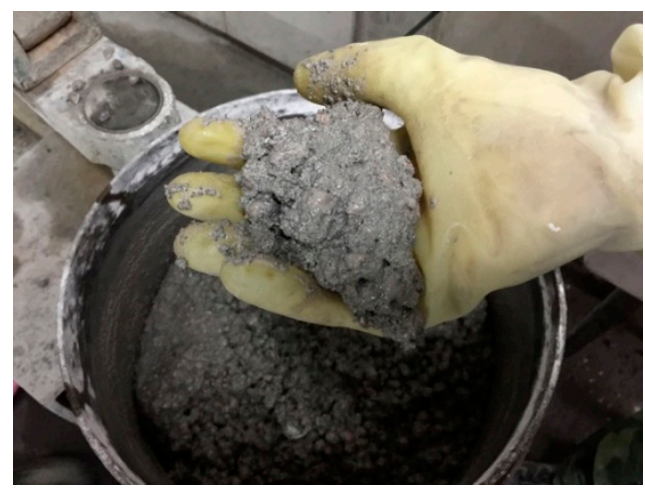

(b)

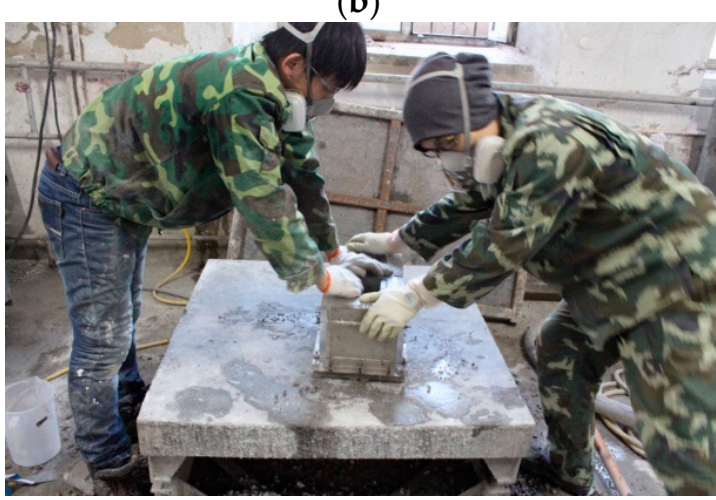

(d)

Figure 5. Cont. 


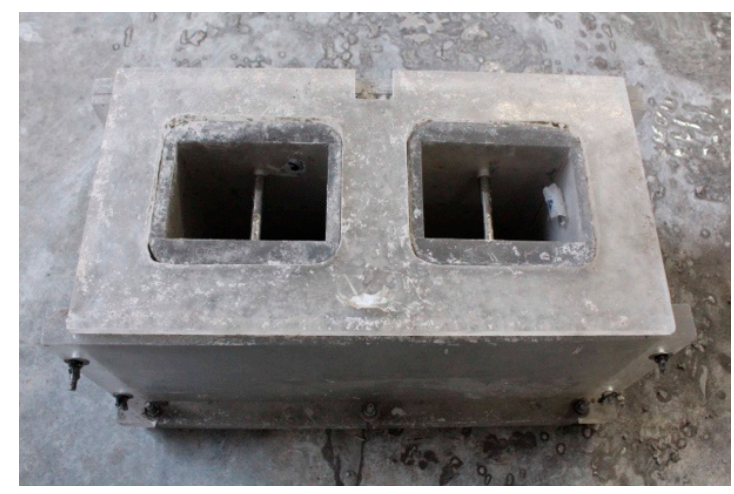

(e)

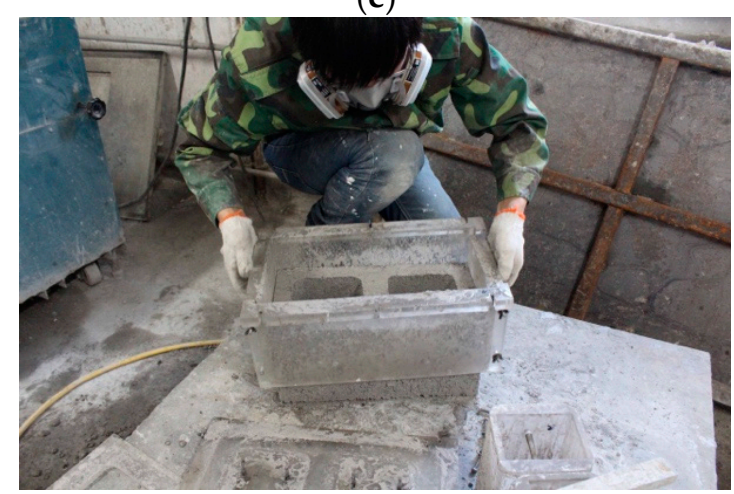

(g)

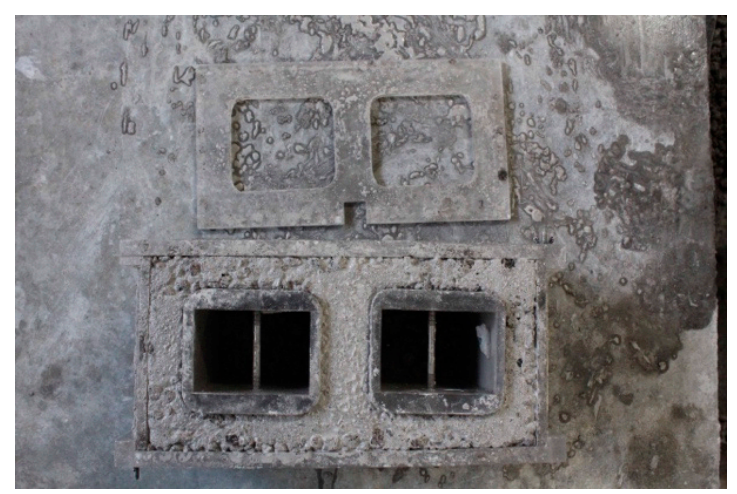

(f)

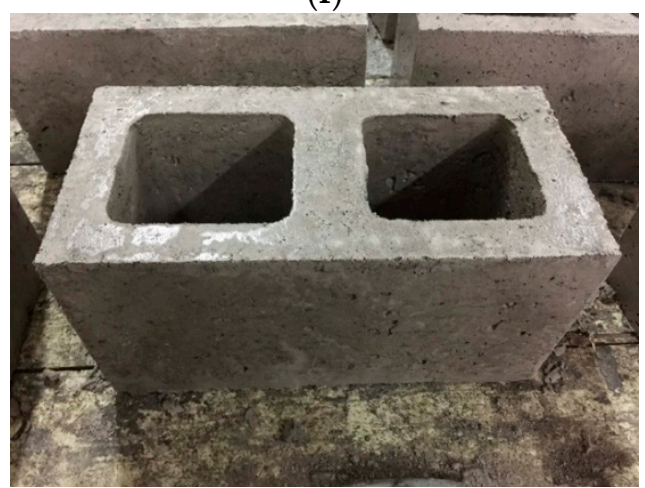

(h)

Figure 5. Preparation of alkali-activated slag concrete hollow block (AASCHB) specimens: (a) homemade plexiglass mold; (b) fresh concrete; (c) molding; (d) mechanical shaking; (e) forming; (f) demolding process 1; (g) demolding process 2; (h) completed AASCHB.

\subsection{Test Procedures}

\subsubsection{Compressive Strength of AASC}

The compressive strength of the AASC cubes was tested after 3, 7, 14, and 28 days curing time according to Chinese Standard GB/T 50081-2002 at a loading rate of $1.0 \mathrm{kN} / \mathrm{s}$ by means of an electrohydraulic machine. The average compressive strength of three samples at each curing age was taken as the compressive strength of the AASC for that age.

\subsubsection{Drying Shrinkage of AASC}

According to Chinese Standard GB/T 50082-2009, the initial length of the AASC specimen was recorded immediately after demolding and measured again with a length comparator every day for 28 days. The average difference in the length of two samples was reported as the drying shrinkage of the mix.

\subsubsection{Compressive and Flexural Strengths of AASCHB Specimens}

The compressive and flexural strength tests of the AASCHB specimens were performed in accordance with the requirements of Chinese Standard GB/T 4111-2013. First, the top and bottom of the AASCHB specimens were leveled using high-strength gypsum. Then, the compressive and flexural strengths were tested by means of $5000-\mathrm{kN}$ and $2000-\mathrm{kN}$ universal compression machines at loading rates of $5.0 \pm 1.0 \mathrm{kN} / \mathrm{s}$ and $250 \pm 50 \mathrm{~N} / \mathrm{s}$, respectively. The average of five specimen strength tests was taken as the strength of the AASCHB for evaluation. 


\subsubsection{Water Absorption and Moisture Content of AASCHB Specimens}

Water absorption (WA) and moisture content (MC) were determined in accordance with Chinese Standard GB/T 4111-2013. For the water absorption and moisture content tests, the AASCHBs were removed from the standard curing room after 28 days, extra water was removed using a dry towel, and the specimens were weighed using an electronic scale to determine $\mathrm{W}_{0}$. The specimens were then immersed in water for $24 \mathrm{~h}$ after which the excess water was again removed with a towel, and the blocks were weighed again to determine $\mathrm{W}_{\mathrm{s}}$. Finally, the specimens were placed in an oven at $105 \pm 5{ }^{\circ} \mathrm{C}$ for at least $24 \mathrm{~h}$, then weighed every $2 \mathrm{~h}$ until the weight difference between the previous two weights was no greater than $0.2 \%$ of the current weight, $\mathrm{W}_{\mathrm{d}}$. The water absorption and moisture content were then calculated using Equations (1) and (2), respectively, as follows:

$$
\begin{aligned}
& \text { WA }(\%)=\left(\mathrm{W}_{\mathrm{s}}-\mathrm{W}_{\mathrm{d}}\right) / \mathrm{W}_{\mathrm{d}} \times 100 \% \\
& \operatorname{MC}(\%)=\left(\mathrm{W}_{0}-\mathrm{W}_{\mathrm{d}}\right) / \mathrm{W}_{\mathrm{d}} \times 100 \%
\end{aligned}
$$

\subsubsection{Scanning Electron Microscopy with Energy-Dispersive Spectrometry}

Scanning electron microscope (SEM) and energy-dispersive spectrometry (EDS) analyses were conducted on an AASC sample after 28 days of curing. The analysis sample was selected from the fractured surface of a concrete cube after the compressive strength test, then crushed into small pieces with a maximum size of $5 \mathrm{~mm}$ and submerged into a 1:1 mixture by volume of ethanol and acetone for 7 days to prevent further hydration, and finally dried in an oven at $60^{\circ} \mathrm{C}$ under vacuum. The sample was attached to a tray using a conductive adhesive and examined by SEM/EDS (ZEISS MERLIN Compact FE-SEM, Germany). Images were obtained under the high-vacuum mode with a spot size of 4.7 , an aperture of 4 , and an accelerating voltage of $20 \mathrm{kV}$.

\section{Results and Discussion}

A series of tests were conducted to determine the optimum mix proportions for an AASCHB. First, the effects of the water-to-slag ratio, sand ratio, $\mathrm{Na}_{2} \mathrm{O}$ content, and silicate modulus on the compressive strength (cube samples) and drying shrinkage (rectangular samples) of the AASC were determined. Based on this result, the optimal mix of AASC (with the highest compressive strength and lowest drying shrinkage) was used to prepare a set of AASCHBs to investigate their physical and mechanical performance.

According to Chinese Standard GB/T 50080-2002, the setting time of the AASC is measured using mortars sifted from the fresh concrete mixtures. However, it was difficult to sift out mortars from the AASC mixtures due to their higher viscosity and short setting time. It is worth noting that Wang et al. [15] have reported that the slump, slump flow, and setting time of an AASC cannot be tested as its viscosity is too high and it exhibits no plasticity when the liquid-solid ratio is 0.45 . Therefore, the setting time and slump of the AASC were not tested; values for the setting time and fluidity of AAS mortars can be found in Reference [12].

\subsection{Compressive Strength and Drying Shrinkage of AASC}

\subsubsection{Effects of the Water-to-Slag Ratio}

First, the effect of the water-to-slag ratio on the compressive strength and drying shrinkage of AASC was studied, and the results are shown in Figure 6. In Figure 6a, it can be observed that when the sand ratio was 0.59 , the late-age ( $\geq 7$ days) compressive strength was smaller at higher water-to-slag ratios, mainly because a higher water-to-slag ratio dilutes the alkaline activator, reducing the compressive strength. Similar results were found by Wang et al. [15], who indicated that the compressive strength decreased as the liquid-to-solid ratio increased from 0.45 to 0.60 . However, there was little difference in this trend when observed for water-to-slag ratios from 0.38 to 0.40 . Furthermore, 
the compressive strength of AAS has been previously observed to decrease as the liquid-to-solid ratio increased from 0.50 to 0.60 [31]. The presence of additional water reduced the compressive strength of AASC by causing an increase in the pore volume of the hardened concrete, as reported by Wang et al. [32]. Indeed, the strength of $\mathrm{NaOH}$-activated slag concretes has generally been found to be related to their total porosity [7]. The early-age compressive strength after three days were 41.0, 42.3 , and 39.7 MPa for water-to-slag ratios of $0.35,0.38$, and 0.40 , respectively, which were $83.5 \%$, $89.4 \%$, and $82.5 \%$ of the corresponding compressive strength after 28 days. In other words, a high early compressive strength was obtained for AASC after as little as three days of curing. This is due to the early activation of the slag occurring as a result of the presence of the alkaline solution, causing the early formation of C-S-H gels [33]. The achievement of such high early compressive strength in concretes based on ordinary Portland cement typically requires the addition of chemical and/or mineral admixtures.

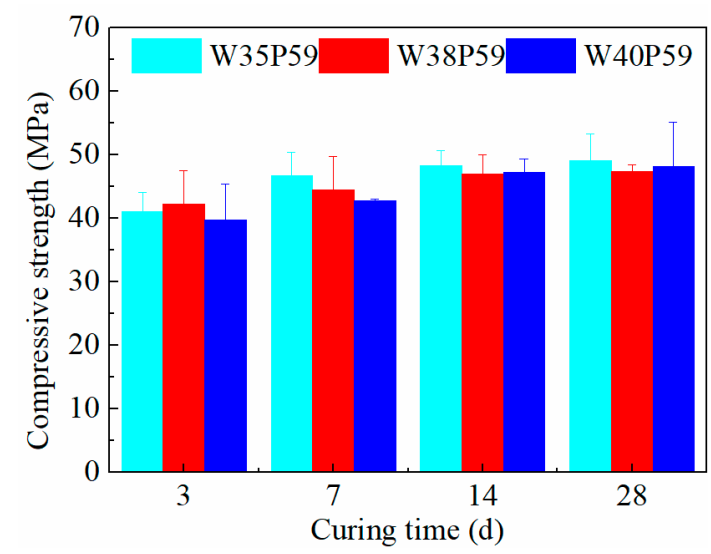

(a)

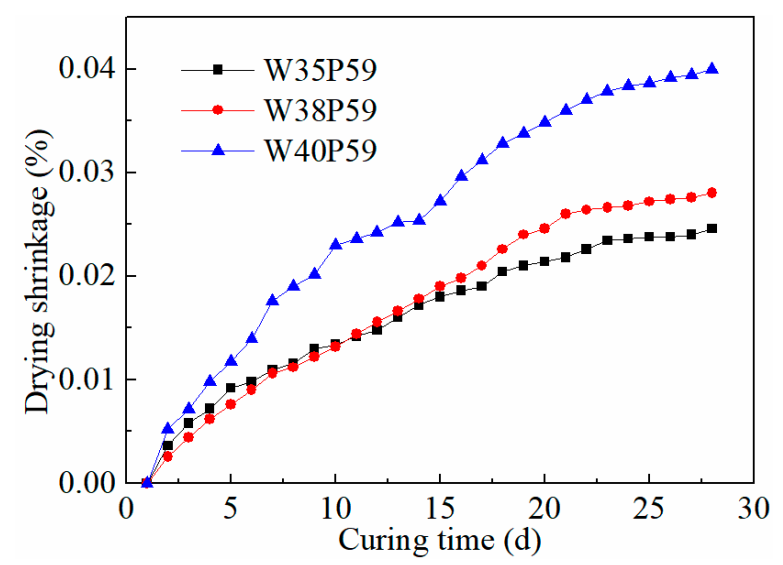

(b)

Figure 6. Effect of water to slag ratio on (a) compressive strength of alkali-activated slag concrete (AASC) specimens; (b) drying shrinkage of AASC specimens.

Drying shrinkage results from the removal of pore water from within the hardened binder due to the evaporation loss of internal water to the environment [27]. On the whole, the drying shrinkage of the AASC specimens was greater at higher water-to-slag ratios (Figure 6b). Before the third day, there were only tiny differences in the development of drying shrinkage among the mix specimens. During 3-28 days, the drying shrinkage increased slightly in specimens with higher water-to-slag ratios, from 0.35 to 0.38 , and then increased dramatically from the specimen with a water-to-slag ratio of 0.38 to that with a water-to-slag ratio of 0.40 . After 28 days, when the water to slag ratios were 0.40 and 0.38 , the drying shrinkages of the AASC specimens were $0.040 \%$ and $0.028 \%$, respectively, which was 1.63 and 1.14 times that of the AASC specimen with a water-to-slag ratio of 0.35 . In general, a higher water-to-slag ratio was found to contribute to the workability of AASC. However, a higher water-to-slag ratio has also been found to result in an increase in drying shrinkage, which may itself lead to shrinkage cracks working as macrodefect points [34]. This inverse relationship between high water-to-slag ratios and drying shrinkage occurs because the presence of more water means that the alkaline activator is diluted, leading to insufficient dissolution of the $\mathrm{Si}$ and $\mathrm{Al}$ ions and the subsequent failure of continuous polymerization reactions to occur.

\subsubsection{Effect of the Sand Ratio}

Figure 7 depicts the change in compressive strength and drying shrinkage with curing time for AASC specimens considering the effect of the sand ratio. It can be seen from Figure 7a that there were different compressive strength development trends at the early and late ages. After three days of curing, the compressive strength of the AASC increased with higher sand ratios from 0.54 to 0.64 , then decreased from a sand ratio of 0.64 to 0.68 ; the greatest compressive strength occurred at a sand 
ratio of 0.64 . After seven days of curing, the compressive strength increased with the increase in sand ratio, increasing most dramatically from a sand ratio of 0.54 to 0.59 , then more gradually from a sand ratio of 0.59 to 0.68 . After seven days of curing, there was little difference between the development trends of compressive strength for different sand ratios. Singh et al. [35] investigated the effect of the paste-to-aggregate ratio on the compressive strength of AASC, indicating that the compressive strength decreased once the paste-to-aggregate ratio was above 0.36 . This was explained as possibly due to part of the activating solution being absorbed by the large quantity of aggregate, reducing the effective water-to-geopolymer solid ratio as well as the paste content in the mixture. Consequently, the optimum sand ratio to provide both the highest early and highest late compressive strengths was determined in this research to be 0.64 .

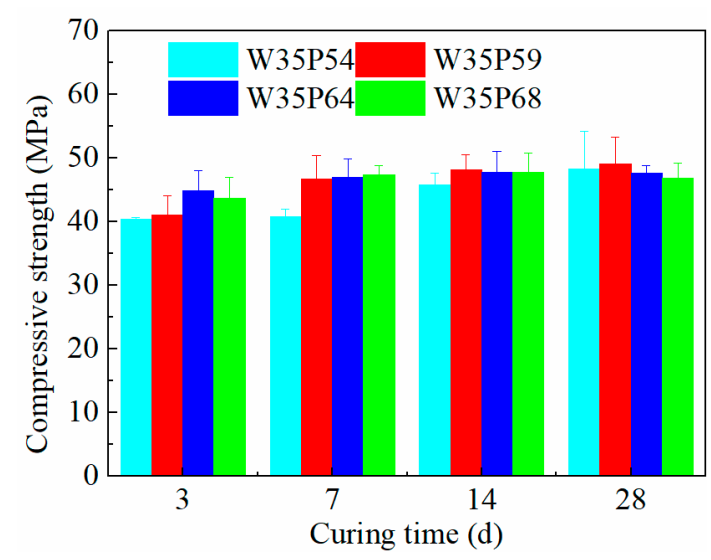

(a)

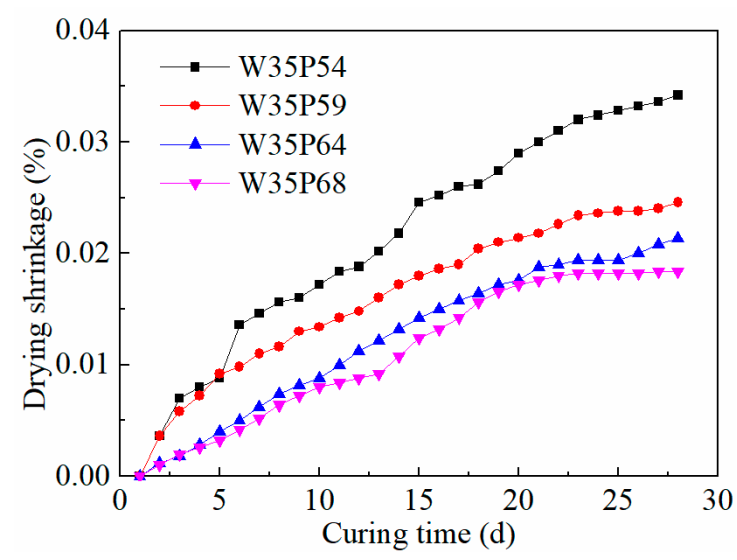

(b)

Figure 7. Effect of sand ratio on (a) compressive strength of AASC specimens; (b) drying shrinkage of AASC specimens.

The drying shrinkage was in the range of $0.018-0.034 \%$ after 28 days for the different sand ratios, as shown in Figure $7 \mathrm{~b}$. The drying shrinkage of the AASC could be observed to decrease as the sand ratio increased from 0.54 to 0.68 . Drying shrinkage is approximately proportional to water loss [36], and because aggregates are dimensionally stable, shrinkage is dominant within the binder paste [27]. Therefore, an increase in binder content in the concrete leads to an increase in the paste volume, naturally resulting in an increase in drying shrinkage $[28,37]$. Moreover, the ceramsite can provide internal curing to AASC due to its water absorption and desorption capabilities, which will directly affect the shrinkage of AASC [38,39].

\subsubsection{Effect of Alkaline Activator}

In Sections 3.1.1 and 3.1.2, the experimental results indicated that the optimum water-to-slag and sand ratios were 0.35 and 0.64 , respectively, in terms of high compressive strength and low drying shrinkage. Based on these ratios, the effects of silicate modulus and $\mathrm{Na}_{2} \mathrm{O}$ content of the alkaline activator on the compressive strength and drying shrinkage of AASC were determined as shown in Figure 8. On the whole, the compressive strength of the AASC increased as the curing time increased and decreased as the silicate modulus or $\mathrm{Na}_{2} \mathrm{O}$ content increased. The compressive strength was in the range of 39.2-48.8 MPa after 7 days. Atis et al. [19] had also shown that the compressive strength of AAS paste decreased as the silicate modulus increased from 0.75 to 1.50 for $\mathrm{Na}_{2} \mathrm{O}$ contents of $6 \%$ and $8 \%$, respectively. The same conclusion was obtained by Garcia et al. [40], who found that the compressive strength of AAS decreased as the $\mathrm{Na}_{2} \mathrm{O}$ content increased from $4 \%$ to $8 \%$ for the silicate modulus between 0 and 2.0. The compressive strength of AAS activated by water glass increased as the $\mathrm{Na}_{2} \mathrm{O}$ content increased from $6 \%$ to $8 \%$, but it decreased when the $\mathrm{Na}_{2} \mathrm{O}$ content continued to increase up to $10 \%$ [41]. However, the opposite conclusion has also been reached. Irrespective of being cured in air or in saturated limewater, the compressive strength of alkali-activated ladle furnace 
slag geopolymer was observed to increase as the alkali agent increased from $4 \%$ to $6 \%$ [42]. A higher $\mathrm{Na}_{2} \mathrm{O}$ content indicates a higher $\mathrm{OH}^{-}$concentration in the alkaline activator, which can accelerate slag dissolution and lead to the formation of larger quantities of reaction products [23]. However, an optimum $\mathrm{OH}^{-}$concentration in $\mathrm{KOH}$ or $\mathrm{NaOH}$ has been observed in relation to the compressive strength of slag-based inorganic polymers [26]. Excess $\mathrm{OH}^{-}$concentration can result in a decrease in final strength, mainly due to the fact that the additional $\mathrm{OH}^{-}$does not react with the raw materials. Instead, with a lower silicate modulus or higher $\mathrm{Na}_{2} \mathrm{O}$ content in the activator, the higher alkalinity solubilizes the water-impermeable layer on the surface of the slag particles [43], resulting in a faster rate of reaction and more rapid formation of reaction products.

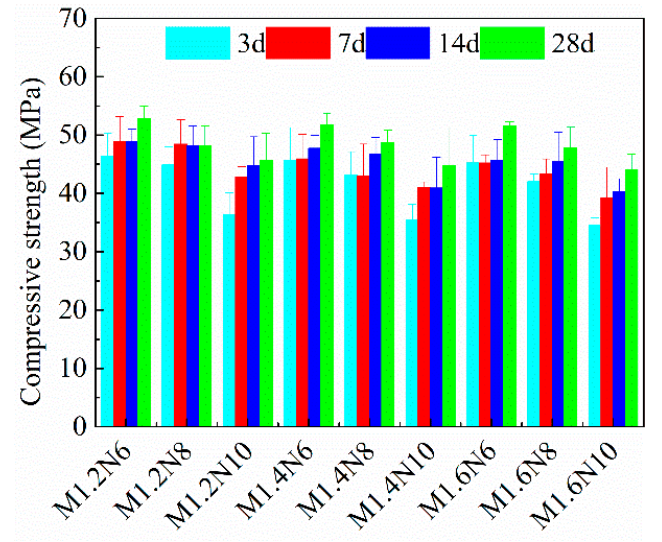

(a)

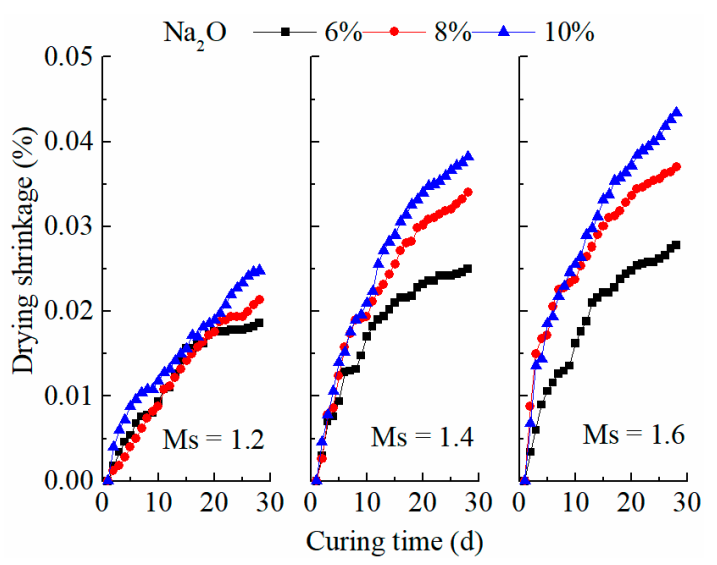

(b)

Figure 8. Effects of silicate modulus and $\mathrm{Na}_{2} \mathrm{O}$ content on (a) compressive strength of AASC specimens; (b) drying shrinkage of AASC specimens.

The drying shrinkage of AASC was observed to increase as the silicate modulus and $\mathrm{Na}_{2} \mathrm{O}$ content increased; thus, both a higher silicate modulus and $\mathrm{Na}_{2} \mathrm{O}$ content can result in higher drying shrinkage. When the $\mathrm{Na}_{2} \mathrm{O}$ content was $8 \%$, the drying shrinkage of the AASC specimens after 28 days with silicate moduli of 1.4 and 1.6 were as much as 1.59 and 1.73 times greater, respectively, than the specimen with a silicate modulus of 1.2. A similar trend was reported in terms of drying shrinkage of AAS pastes at silicate moduli between 0.75 and 1.50 and $\mathrm{Na}_{2} \mathrm{O}$ contents between $4 \%$ and $8 \%$ [19]. The drying shrinkage of geopolymer concrete was also observed to increase as the sodium silicate to sodium hydroxide ratio increased from 1.5 to 2.5 [44]. Previous research has assumed that an increase in the portion of alkali agent helps to dissolve more of the $\mathrm{Si}$ and $\mathrm{Al}$ ions that participate in inorganic polymerization reactions, thus contributing to the observed increase in shrinkage over time [42]. It has also been observed that an increase in the portion of sodium oxide in blended alkali-activated binders results in a decrease in the measured shrinkage [45]. The pore structure of alkali-activated slag concrete is much finer and more complex [46], and this tightness of the pore structure may influence the degree of shrinkage. In previous studies $[19,47]$, it has been reported that the drying shrinkage of slag mortar activated by liquid sodium silicate increases with the increase in sodium concentration at a constant $\mathrm{SiO}_{2} / \mathrm{Na}_{2} \mathrm{O}$ ratio. This indicates that the quantity of alkaline activator in a mix is a key factor influencing the drying shrinkage of AASC.

\subsection{Performance of $A A S C H B$ Specimens}

Based on the above mix test results, an AASC mix with a water-to-slag ratio of 0.35 , sand ratio of 0.64 , silicate modulus of 1.2 , and $\mathrm{Na}_{2} \mathrm{O}$ content of $6 \%$ was initially chosen as the optimal mixture (M1.2N6) to provide the maximum compressive strength and minimum drying shrinkage. However, mix M1.2N6 tended to set quickly and thus necessitated rapid placement and consolidation in the molds. According to a previous study [12], the setting time of the mortar corresponding to a silicate modulus of 1.2 and $\mathrm{Na}_{2} \mathrm{O}$ content of $6 \%$ is too short, limiting its potential applications. However, 
the setting time of M1.2N8 was somewhat longer than that of M1.2N6, while the compressive strength of M1.2N8 was $96.8 \%, 99.2 \%, 98.8 \%$, and $91.3 \%$ that of M1.2N6 after 3, 7, 14, and 28 days, respectively, and never less than $45 \mathrm{MPa}$. Additionally, the drying shrinkage of M1.2N8 was only $15 \%$ greater than that of M1.2N6, or about $0.02 \%$ after 28 days. As a result of these concerns and the relative suitability of its other material properties, Mix M1.2N8 was used to prepare the AASCHBs investigated in this study.

The determined mechanical and physical properties of the AASCHBs are provided in Table 4. The average compressive strength was 17.2 MPa with a coefficient of variation of $7.4 \%$ and a minimum value of five compressive strength tests of 15.4 MPa. According to Chinese Standard GB/T 8239-2014, a strength grade of MU15 was determined for the AASCHB using the average and minimum compressive strengths as they were greater than $15.0 \mathrm{MPa}$ and $12.0 \mathrm{MPa}$, respectively. The flexural strength (1.2 MPa) of the AASCHB was nearly $7 \%$ of its compressive strength. The water absorption of the AASCHB was $9.95 \%$ with a coefficient of variation of $5.4 \%$. The water absorption and drying shrinkage of a load-bearing hollow concrete block should be less than $10 \%$ and $0.045 \%$, respectively, according to Chinese Standard GB/T 8239-2014. Consequently, the AASCHB cast from Mix M1.2N8 can be classified as having a strength grade of MU15 and is therefore suitable for use as a load-bearing hollow concrete block.

Table 4. Mechanical and physical properties of AASCHBs cast from Mix M1.2N8.

\begin{tabular}{ccccc}
\hline Properties & Values & Mean Value & SD & CV \\
\hline & 17.5 & & & \\
Compressive strength (MPa) & 15.4 & & 1.27 & 0.074 \\
& 18.7 & 17.2 & & \\
& 16.6 & & & \\
& 17.9 & & 0.10 & 0.083 \\
Flexural strength (MPa) & 1.3 & 1.2 & & \\
& 1.2 & & & \\
& 1.1 & & 0.53 & 0.054 \\
\hline Water absorption (\%) & 1.2 & 9.95 & & \\
\hline Moisture content (\%) & 10.43 & & & \\
\hline
\end{tabular}

Note: SD is standard deviation and CV is coefficient of variation.

\subsection{Microstructure}

There was a direct and intimate connection found between the macroperformance and microstructure of the AASC in this study. Figure 9 shows an SEM image of an AASC with a silicate modulus of 1.2 and $\mathrm{Na}_{2} \mathrm{O}$ content of $8 \%$ (M1.2N8) after 28 days of curing at 1000 times magnification. As can be seen, a dense structure and uniform hydration products are obvious in the AASC. No obvious interfacial transition zone was found in the AASC; this is consistent with the strong interactions between the aggregate and paste, which play such an important role in providing compressive strength in the concrete [8]. The reaction products of the AASC were symmetrical, close-grained and cemented with the surrounding binding products, and the specimen did not exhibit massive $\mathrm{Ca}(\mathrm{OH})_{2}$ formations like ordinary Portland cement concrete. Additionally, in the AASC, crystalloids could be observed to complete and link with each other. All of these qualities make for excellent integrated and close-grained properties in AASC, improving its mechanical properties. 


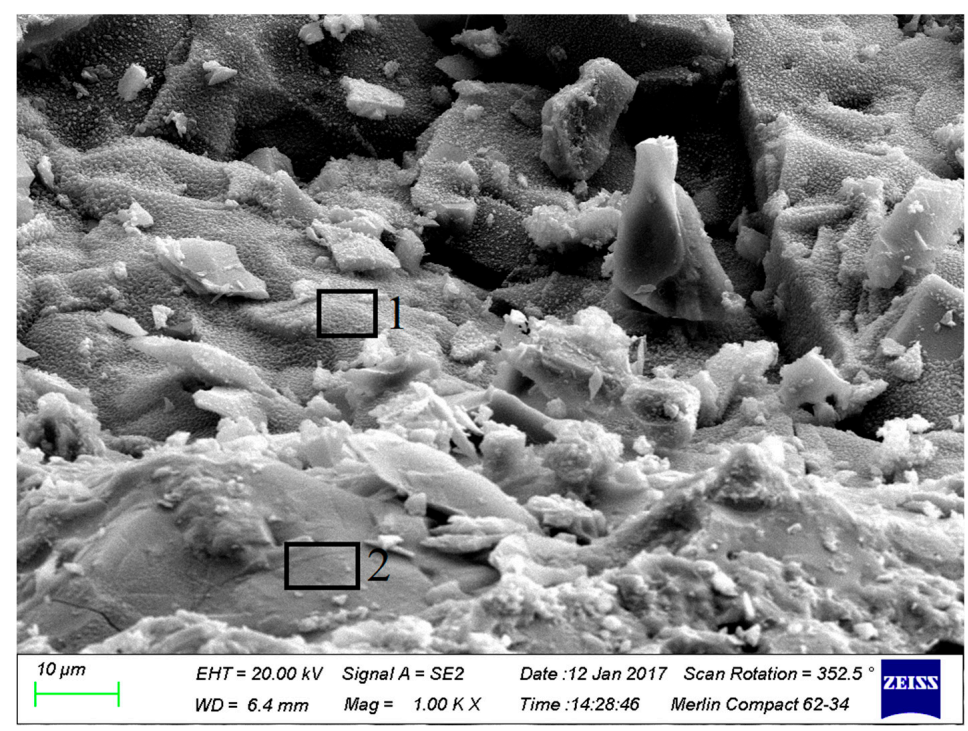

Figure 9. Scanning electron microscope (SEM) image of AASC with a silicate modulus of 1.2 and $\mathrm{Na}_{2} \mathrm{O}$ content of $8 \%$ after 28 days.

The EDS results of the AASC specimens are shown in Figure 10. The reaction products in the AASC showed amounts of $\mathrm{Ca}, \mathrm{Si}, \mathrm{Na}, \mathrm{Al}$, and $\mathrm{O}$ elements, and the $\mathrm{Ca}: \mathrm{Si}$ and $\mathrm{Ca}$ :Na ratios were in the range of $0.64-0.83$ and $0.56-0.66$, respectively, which is much lower than the Ca:Si ratio of C-S-H in neat Portland cement pastes (between 1.2 and 2.3) [48] and within the Ca:Si ratio of C-S-H in alkali-activated slag (between 0.5 and 1.1) [49]. The main hydration products of AASC are C-S-H (or N-A-S-H) gel, alkaline aluminosilicate and zeolite mineral, and $\left[\mathrm{SiO}_{4}\right]^{4-}$ and $\left[\mathrm{AlO}_{4}\right]^{5-}$ tetrahedrons forming polymeric aluminum-oxygen-silicon network structure products synthesized by mutual oxygen, and they contain no $\mathrm{Ca}(\mathrm{OH})_{2}$ at room temperature [1,49-52]. Close-grained hydration products without visible transition strips make the structure of AASC more compact, giving it excellent mechanical performance.

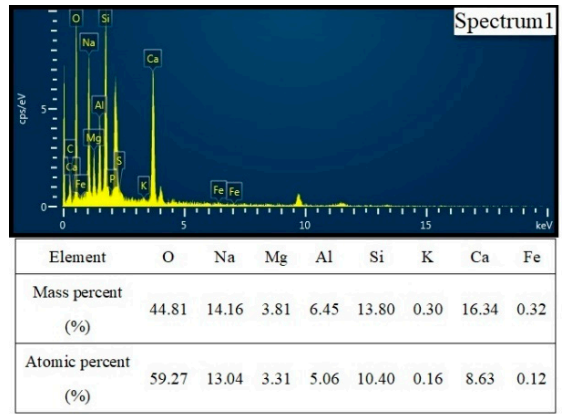

(a)

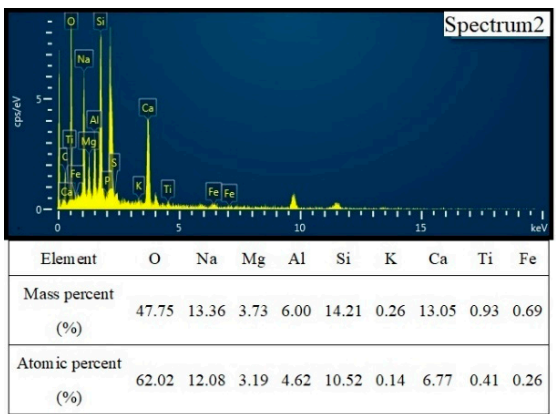

(b)

Figure 10. Energy-dispersive spectrometry (EDS) images of AASC with a silicate modulus of 1.2 and $\mathrm{Na}_{2} \mathrm{O}$ content of $8 \%$ after 28 days: (a) Spectrum 1 ; (b) Spectrum 2.

The observed density of the pore structure of AASC provides a great deal of its strength. Previously, the authors of Reference [12] indicated that the pore size distribution of alkali-activated slag mortars included three ranges $(<50 \mathrm{~nm}, 50-10,000 \mathrm{~nm},>10,000 \mathrm{~nm}$ ) within which the pore structure $<50 \mathrm{~nm}$ played a significant role in the drying shrinkage: the higher the volume of pores $<50 \mathrm{~nm}$, the greater was the drying shrinkage resulting from the higher contracting stress influenced by the finer capillary pores [53]. 


\section{Conclusions}

This study investigated the ideal mix and resulting properties of alkali-activated slag ceramsite concrete hollow blocks. The investigated parameters were the water-to-slag ratio, sand ratio, silicate modulus, and $\mathrm{Na}_{2} \mathrm{O}$ content. The primary conclusions of this study are as follows:

(1) The compressive strength of alkali-activated slag concrete decreased with increasing water-to-slag ratio, silicate modulus, and $\mathrm{Na}_{2} \mathrm{O}$ content. The effects of the silicate modulus and $\mathrm{Na}_{2} \mathrm{O}$ content on the mechanical performance were quite obvious, and an optimum sand ratio for providing maximum compressive strength was observed in the range of 0.54-0.68.

(2) The drying shrinkage of alkali-activated slag concrete increased as the water-to-slag ratio, silicate modulus, and $\mathrm{Na}_{2} \mathrm{O}$ content increased and as the sand ratio decreased.

(3) The optimum mix for preparing the alkali-activated slag concrete hollow block contained a water-to-slag ratio of 0.35 , sand ratio of 0.64 , silicate modulus of 1.2 , and $\mathrm{Na}_{2} \mathrm{O}$ content of $8 \%$, providing optimal workability, high compressive strength, and low drying shrinkage. The hydration products of the selected mix were close-grained and symmetrical, which provided improved compressive strength.

(4) The alkali-activated slag concrete hollow block made of Mix M1.2N8 can be classified as strength grade of MU15 and is appropriate for use as a load-bearing hollow concrete block.

The proposed use of alkali-activated slag in hollow concrete blocks shows great promise for not only providing suitable material for future construction but also for reducing industrial waste and the emissions of the cement manufacturing industry.

Additional mechanical properties, such as shear strength, bending tensile strength, axial tension strength, and compressive strength of the masonry with different grades of alkali-activated slag concrete hollow blocks, should be investigated to further examine the effects of the water-to-slag ratio, sand ratio, silicate modulus, and $\mathrm{Na}_{2} \mathrm{O}$ content in more detail.

Author Contributions: Conceptualization, Y.W. and W.Z.; Investigation, Z.J., W.H., and X.Z.; Writing-Original Draft Preparation, Z.J.; Writing-Review \& Editing, Z.J.; Supervision, Y.W. and W.Z.; Funding Acquisition, Y.W.

Funding: National Natural Science Foundation of China [grant number 51478142].

Acknowledgments: This research was funded by the National Natural Science Foundation of China [grant number 51478142].

Conflicts of Interest: The authors declare no conflict of interest.

\section{References}

1. Puertas, F.; Martínez-Ramírez, S.; Alonso, S.; Vázquez, T. Alkali-activated fly ash/slag cements: Strength behaviour and hydration products. Cem. Concr. Res. 2000, 30, 1625-1632. [CrossRef]

2. Jiao, Z.; Wang, Y.; Zheng, W.; Huang, W. Effect of dosage of sodium carbonate on the strength and drying shrinkage of sodium hydroxide based alkali-activated slag paste. Constr. Build. Mater. 2018, 179, 11-24. [CrossRef]

3. Živica, V. Effects of type and dosage of alkaline activator and temperature on the properties of alkali-activated slag mixtures. Constr. Build. Mater. 2007, 21, 1463-1469. [CrossRef]

4. Parronrubio, M.E.; Perezgarcía, F.; Gonzalezherrera, A.; Rubiocintas, M.D. Concrete properties comparison when substituting a 25\% cement with slag from different provenances. Materials 2018, 11, 1029. [CrossRef]

5. Berndt, M.L. Properties of sustainable concrete containing fly ash, slag and recycled concrete aggregate. Constr. Build. Mater. 2009, 23, 2606-2613. [CrossRef]

6. Provis, J.L.; Palomo, A.; Shi, C. Advances in understanding alkali-activated materials. Cem. Concr. Res. 2015, 78, 110-125. [CrossRef]

7. Puertas, F.; González-Fonteboa, B.; González-Taboada, I.; Alonso, M.M.; Torres-Carrasco, M.; Rojo, G.; Martínez-Abella, F. Alkali-activated slag concrete: Fresh and hardened behaviour. Cem. Concr. Compos. 2018, 85, 22-31. [CrossRef] 
8. Bernal, S.A.; Mejía de Gutiérrez, R.; Pedraza, A.L.; Provis, J.L.; Rodriguez, E.D.; Delvasto, S. Effect of binder content on the performance of alkali-activated slag concretes. Cem. Concr. Res. 2011, 41, 1-8. [CrossRef]

9. Fu, Y.; Cai, L.; Wu, Y. Freeze-Thaw cycle test and damage mechanics models of alkali-activated slag concrete. Constr. Build. Mater. 2011, 25, 3144-3148. [CrossRef]

10. Li, Z.; Li, S. Carbonation resistance of fly ash and blast furnace slag based geopolymer concrete. Constr. Build. Mater. 2018, 163, 668-680. [CrossRef]

11. Aydin, S.; Baradan, B. Effect of activator type and content on properties of alkali-activated slag mortars. Compos. Part B Eng. 2014, 57, 166-172. [CrossRef]

12. Jiao, Z.; Wang, Y.; Zheng, W.; Huang, W. Pottery sand as fine aggregate for preparing alkali-activated slag mortar. Adv. Mater. Sci. Eng. 2018, 2018. [CrossRef]

13. Kovtun, M.; Kearsley, E.P.; Shekhovtsova, J. Chemical acceleration of a neutral granulated blast-furnace slag activated by sodium carbonate. Cem. Concr. Res. 2015, 72, 1-9. [CrossRef]

14. Keulen, A.; Yu, Q.L.; Zhang, S.; Grünewald, S. Effect of admixture on the pore structure refinement and enhanced performance of alkali-activated fly ash-slag concrete. Constr. Build. Mater. 2018, 162, 27-36. [CrossRef]

15. Wang, C.-C.; Wang, H.-Y.; Chen, B.-T.; Peng, Y.-C. Study on the engineering properties and prediction models of an alkali-activated mortar material containing recycled waste glass. Constr. Build. Mater. 2017, 132, 130-141. [CrossRef]

16. Wang, W.-C.; Wang, H.-Y.; Lo, M.-H. The fresh and engineering properties of alkali activated slag as a function of fly ash replacement and alkali concentration. Constr. Build. Mater. 2015, 84, 224-229. [CrossRef]

17. Chi, M. Effects of dosage of alkali-activated solution and curing conditions on the properties and durability of alkali-activated slag concrete. Constr. Build. Mater. 2012, 35, 240-245. [CrossRef]

18. Ben Haha, M.; Le Saout, G.; Winnefeld, F.; Lothenbach, B. Influence of activator type on hydration kinetics, hydrate assemblage and microstructural development of alkali activated blast-furnace slags. Cem. Concr. Res. 2011, 41, 301-310. [CrossRef]

19. Duran Atiş, C.; Bilim, C.; Çelik, Ö.; Karahan, O. Influence of activator on the strength and drying shrinkage of alkali-activated slag mortar. Constr. Build. Mater. 2009, 23, 548-555. [CrossRef]

20. Collins, F.; Sanjayan, J.G. Effect of pore size distribution on drying shrinkage of alkali-activated slag concrete. Cem. Concr. Res. 2000, 30, 1401-1406. [CrossRef]

21. Zhang, W.; Zakaria, M.; Hama, Y. Influence of aggregate materials characteristics on the drying shrinkage properties of mortar and concrete. Constr. Build. Mater. 2013, 49, 500-510. [CrossRef]

22. Cao, J.; Chung, D.D.L. Microstructural effect of the shrinkage of cement-based materials during hydration, as indicated by electrical resistivity measurement. Cem. Concr. Res. 2004, 34, 1893-1897. [CrossRef]

23. Ravikumar, D.; Neithalath, N. Effects of activator characteristics on the reaction product formation in slag binders activated using alkali silicate powder and $\mathrm{NaOH}$. Cem. Concr. Compos. 2012, 34, 809-818. [CrossRef]

24. Rashad, A.M.; Zeedan, S.R.; Hassan, A.A. Influence of the activator concentration of sodium silicate on the thermal properties of alkali-activated slag pastes. Constr. Build. Mater. 2016, 102, 811-820. [CrossRef]

25. Karakoç, M.B.; Türkmen, İ.; Maraş, M.M.; Kantarci, F.; Demirboğa, R.; Uğur Toprak, M. Mechanical properties and setting time of ferrochrome slag based geopolymer paste and mortar. Constr. Build. Mater. 2014, 72 , 283-292. [CrossRef]

26. Komnitsas, K.; Zaharaki, D.; Perdikatsis, V. Effect of synthesis parameters on the compressive strength of low-calcium ferronickel slag inorganic polymers. J. Hazard. Mater. 2009, 161, 760-768. [CrossRef] [PubMed]

27. Thomas, R.J.; Lezama, D.; Peethamparan, S. On drying shrinkage in alkali-activated concrete: Improving dimensional stability by aging or heat-curing. Cem. Concr. Res. 2017, 91, 13-23. [CrossRef]

28. Bissonnette, B.; Pierre, P.; Pigeon, M. Influence of key parameters on drying shrinkage of cementitious materials. Cem. Concr. Res. 1999, 29, 1655-1662. [CrossRef]

29. Dahmen, J.; Kim, J.; Ouellet-Plamondon, C.M. Life cycle assessment of emergent masonry blocks. J. Clean. Prod. 2018, 171, 1622-1637. [CrossRef]

30. Munoz, J.F.; Easton, T.; Dahmen, J. Using alkali-activated natural aluminosilicate minerals to produce compressed masonry construction materials. Constr. Build. Mater. 2015, 95, 86-95. [CrossRef]

31. Wang, W.-C.; Chen, B.-T.; Wang, H.-Y.; Chou, H.-C. A study of the engineering properties of alkali-activated waste glass material (AAWGM). Constr. Build. Mater. 2016, 112, 962-969. [CrossRef]

32. Wang, S.-D.; Scrivener, K.L.; Pratt, P.L. Factors affecting the strength of alkali-activated slag. Cem. Concr. Res. 1994, 24, 1033-1043. [CrossRef] 
33. Manjunath, R.; Narasimhan, M.C. An experimental investigation on self-compacting alkali activated slag concrete mixes. J. Build. Eng. 2018, 17, 1-12. [CrossRef]

34. Allahverdi, A.; Kani, E.N.; Yazdanipour, M. Effects of blast-furnace slag on natural pozzolan-based geopolymer cement. Ceram. Sil. 2011, 55, 68-78.

35. Singh, B.; Rahman, M.R.; Paswan, R.; Bhattacharyya, S.K. Effect of activator concentration on the strength, ITZ and drying shrinkage of fly ash/slag geopolymer concrete. Constr. Build. Mater. 2016, 118, 171-179. [CrossRef]

36. Bazant, Z.P. Prediction of concrete creep and shrinkage: Past, present and future. Nucl. Eng. Des. 2001, 203, 27-38. [CrossRef]

37. Han, M.Y.; Lytton, R.L. Theoretical prediction of drying shrinkage of concrete. J. Mater. Civ. Eng. 1995, 7, 204-207. [CrossRef]

38. Wang, X.F.; Fang, C.; Kuang, W.Q.; Li, D.W.; Han, N.X.; Xing, F. Experimental investigation on the compressive strength and shrinkage of concrete with pre-wetted lightweight aggregates. Constr. Build. Mater. 2017, 155, 867-879. [CrossRef]

39. Ji, T.; Zheng, D.-D.; Chen, X.-F.; Lin, X.-J.; Wu, H.-C. Effect of prewetting degree of ceramsite on the early-age autogenous shrinkage of lightweight aggregate concrete. Constr. Build. Mater. 2015, 98, 102-111. [CrossRef]

40. GarcãA, J.I.E.; Campos-Venegas, K.; Gorokhovsky, A.; Fernãndez, A. Cementitious composites of pulverised fuel ash and blast furnace slag activated by sodium silicate: Effect of $\mathrm{Na}_{2} \mathrm{O}$ concentration and modulus. Br. Ceram. Trans. 2006, 105, 201-208.

41. Cihangir, F.; Ercikdi, B.; Kesimal, A.; Deveci, H.; Erdemir, F. Paste backfill of high-sulphide mill tailings using alkali-activated blast furnace slag: Effect of activator nature, concentration and slag properties. Miner. Eng. 2015, 83, 117-127. [CrossRef]

42. Wang, W.-C.; Wang, H.-Y.; Tsai, H.-C. Study on engineering properties of alkali-activated ladle furnace slag geopolymer. Constr. Build. Mater. 2016, 123, 800-805. [CrossRef]

43. Song, S.J.; Jennings, H.M. Pore solution chemistry of alkali-activated ground granulated blast-furnace slag. Cem. Concr. Res. 1999, 29, 159-170. [CrossRef]

44. Deb, P.S.; Nath, P.; Sarker, P.K. Drying shrinkage of slag blended fly ash geopolymer concrete cured at room temperature. Proc. Eng. 2015, 125, 594-600. [CrossRef]

45. Chi, M.; Huang, R. Binding mechanism and properties of alkali-activated fly ash/slag mortars. Constr. Build. Mater. 2013, 40, 291-298. [CrossRef]

46. Provis, J.L.; Myers, R.J.; White, C.E.; Rose, V.; van Deventer, J.S.J. X-ray microtomography shows pore structure and tortuosity in alkali-activated binders. Cem. Concr. Res. 2012, 42, 855-864. [CrossRef]

47. Bakharev, T.; Sanjayan, J.G.; Cheng, Y.B. Alkali activation of Australian slag cements. Cem. Concr. Res. 1999, 29, 113-120. [CrossRef]

48. Richardson, I.G. The nature of C-S-H in hardened cements. Cem. Concr. Res. 1999, 29, 1131-1147. [CrossRef]

49. Brough, A.R.; Atkinson, A. Sodium silicate-based, alkali-activated slag mortars: Part I. Strength, hydration and microstructure. Cem. Concr. Res. 2002, 32, 865-879. [CrossRef]

50. Pacheco-Torgal, F.; Castro-Gomes, J.; Jalali, S. Alkali-activated binders: A review: Part 1. Historical background, terminology, reaction mechanisms and hydration products. Constr. Build. Mater. 2008, 22, 1305-1314. [CrossRef]

51. Wang, S.-D.; Scrivener, K.L. Hydration products of alkali activated slag cement. Cem. Concr. Res. 1995, 25, 561-571. [CrossRef]

52. Kiventerä, J.; Lancellotti, I.; Catauro, M.; Poggetto, F.D.; Leonelli, C.; Illikainen, M. Alkali activation as new option for gold mine tailings inertization. J. Clean. Prod. 2018, 187, 76-84. [CrossRef]

53. Gu, Y.-m.; Fang, Y.-h.; You, D.; Gong, Y.-f.; Zhu, C.-h. Properties and microstructure of alkali-activated slag cement cured at below- and about-normal temperature. Constr. Build. Mater. 2015, 79, 1-8. [CrossRef]

(C) 2018 by the authors. Licensee MDPI, Basel, Switzerland. This article is an open access article distributed under the terms and conditions of the Creative Commons Attribution (CC BY) license (http:/ / creativecommons.org/licenses/by/4.0/). 